\title{
Interest groups in multiple streams: specifying their involvement in the framework
}

Patrycja Rozbicka 1,*

Email p.rozbicka@aston.ac.uk

Florian Spohr 2

Email florian.spohr@ruhr-uni-bochum.de

1 School of Languages and Social Sciences, Aston University, Aston Triangle, Birmingham, B4 7ET England, UK

2 Faculty of Social Sciences, Ruhr University Bochum, Universitätsstr. 150, 44780 Bochum, Germany

\section{Abstract}

Although interests inhabit a central place in the multiple streams framework (MSF), interest groups have played only a minor role in theoretical and empirical studies until now. In Kingdon's original conception, organized interests are a key variable in the politics stream. Revisiting Kingdon's concept with a particular focus on interest groups and their activities-in different streams and at various levels - in the policy process, we take this argument further. In particular, we argue that specifying groups' roles in other streams adds value to the explanatory power of the framework. To do this, we look at how interest groups affect problems, policies, and politics. The influence of interest groups within the streams is explained by linking the MSF with literature on interest intermediation. We show that depending on the number of conditions and their activity level, interest groups can be involved in all three streams. We illustrate this in case studies reviewing labor market policies in Germany and chemicals regulation at the European level. 


\section{Keywords}

Chemicals regulation

European Union

Germany

Interest groups

Labor market

Multiple streams

\section{Introduction}

John W. Kingdon posited that the answer to the questions of why some subjects rise on agendas and others do not and why some alternatives receive more attention than others lies in the processes through which different actors affect agendas and alternatives. By introducing three streams of processes - problems, policies, and politics - he indicated, respectively, that actors recognize problems, generate proposals for public policy changes, and engage in political activities such as election campaigns and pressure group lobbying (Kingdon 2003). While organized interests were a crucial variable in the original outline of the multiple streams framework (MSF, Kingdon 2003), its importance has diminished as a result of the refinements and amendments the framework has gone through since 1984.

Nowadays, interest groups play only a minor role in both theoretical and empirical studies conducted using the MSF. If they are included in analyses, they either are usually a variable in the politics stream (Bundgaard and Vrangbæk 2007; Nagel 2009) or are said to assume the role of policy entrepreneurs (Bendel 2006; Zahariadis 2008; Rüb 2009). However, we argue that limiting the role of interest groups to the politics stream may result in incomplete analyses of policy processes, since they can also be crucial actors in the problem and policy streams.

The aim of this article is to show how the inclusion of interest groups in the MSF can improve the framework's explanatory power. We start with the premise taken from Kingdon: The activities of actors involved in policy processes can be positive, like promoting new courses of 
government action, or negative, like seeking to block changes in public policy (Kingdon 2003, pp. 48-49). The literature on interest intermediation informs us that interest groups can engage in either of these activities (Baumgartner and Jones 1991). Implemented programs tend to be protected by lobbies built around them. The goal and ability of vetoing change distinguish interest groups from policy entrepreneurs, who are willing to invest their resources in return for high agenda status or enactment of policies they favor (Kingdon 2003 ). Interest groups are also distinct from the recently introduced concept of problem brokers who stress the necessity of changing the status quo (Knaggård 2015). In contrast, interest groups do not only pursue their own goals, but also aim to avoid undesired legislation.

The following sections explore venues for interest groups' inclusion in the problem, policy and politics streams. In each stream, the role of interest groups is revisited and remarks are made based on the insights from the literature on interest intermediation. We explain the role and impact of interest groups in the streams by means of their resources, their skills and strategies, and their embeddedness in the institutional structures. In addition, we explore whether the same factors affect groups' role at the domestic and supranational levels. We thus rehearse a classic theme in the interest group literature, namely whether different arenas provide diverse possibilities for interests (Schattschneider 1975; Truman 1951). To illustrate our arguments, we provide examples in two case studies, one on labor market policy in Germany and the other on chemicals regulation in the European Union (EU). We conclude with a speculation on future directions in the study of the MSF and interest groups.

\section{Interest groups in problem, policy, and politics streams}

\section{Problem stream}

The process of problem recognition and definition, of fixing attention on one problem rather than another, is a central part of agenda setting (Kingdon 2003, p. 115). The dynamic of the problem stream is affected by indicators, feedback provided by running programs, focusing events, and the capacity of institutions to deal with potential problems (for 
details, see: Zahariadis 2014). However, the problem stream lacks agency (Knaggård 2015), and focusing on interest groups' activities can help contribute to the understanding of how problems are recognized and defined. Boscarino (2009), for example, provided empirical evidence that interest groups search the problem stream for issues to attach to their pet policies. Nedlund and Garpenby (2014) illustrate how problem frame differences shape the puzzling of a policy problem. And interest group literature tells us that groups are capable of controlling the image of a problem through the use of rhetoric and policy analysis (Baumgartner and Jones 1991, p. 1045). Problems contain a perceptual, interpretive element (Kingdon 2003, p. 110), which enables interested actors to interpret and frame them in a specific way and thereby tell a story about how a problem should be understood. Because every description of a situation reflects only one of many points of view, there is nothing preventing interest groups from fashioning portrayals to promote their own favored policies (Stone 2002). Consequently, one role for interest groups in the problem stream involves framing conditions that they perceive as problematic.

Interest group scholars established that policymakers are more receptive to feedback providing interest groups (Hall and Deardorff 2006; Kohler-Koch 1994). In the ambiguous environment of fragmented public policy, legislators seeking reelection hope to champion problems that are of interest to a larger public. Groups with the appropriate knowledge and expertise, including especially information about the interests of a broader constituency, are in the strongest position to influence decision-makers' perception of the problems. By analyzing indicators and assuring broad public appeal, interest groups can boost an issue higher on policymakers' agenda or oppose an item moving it down the list of priorities or even off the agenda.

At the national level, a key element in the delivery of groups' analysis is their institutional embeddedness, defined as the access individual groups enjoy to public actors, and may include various types of institutionalized group participation in policymaking (Beyers 2002, pp. 591-592). Incorporation in public boards and committees is often a main indicator of groups' inclusion (Öberg et al. 2011). Corporatist systems of interest mediation are frequently pointed to as the best 
examples of systems with high levels of institutionalized, interest group integration into decision-making processes. However, pluralist systems exhibit similar structures of group participation (Rhodes and Marsh 1992). Nonetheless, not all groups benefit equally from institutional embeddedness. Binderkrantz (2005) concludes that some groups are regular policymaking insiders, while other groups may be outsiders with little or no access to policymakers. Thus, groups embedded in national policy processes - e.g., via public committees or national advisory boards - have a greater impact on problem definition than those not included.

While the embeddedness in domestic institutional structures is an important factor in securing agenda influence at the national level, there is a broad consensus that the feedback that groups produce alone secures similar influence at the supranational level (Lowery et al. 2008; Quittkat and Kotzian 2011; Rietig 2014). When looking in particular at the European Union's supranational structure, Bouwen (2002, 2004) argues that the type of feedback that groups produce is the most important resource at their disposal to gain access to different policymakers. The policy officials in the European Commission (CEC) are most interested in expertise and technical know-how related to understanding the market and public demands; the members of European Parliament (EP) seek knowledge on aggregated needs and interests in the European economic arena; and the Council's members look for information on the aggregated needs and interests of specific domestic sectors. As a consequence, it is more probable that business groups, which have more resources to generate expertise, will be a source of feedback for the Commission; European associations will have higher degree of access to the EP, and national associations will be more welcomed in the Council of Ministers.

Based on the inputs presented above, we hypothesize that the power of interest groups over problem definition is a sum of their framing skills and public appeal that they provide to the policymakers. Depending on the level at which the problem stream is analyzed, the examination of the embeddedness of groups in domestic institutional structures (national level) and the feedback which policymakers require and 
groups can provide (European level) are additional factors which could further explain groups' impact on the problem stream.

\section{Policy stream}

The policy stream comprises ideas that compete to win acceptance. The position of interest groups in the policy communities, where ideas are generated, is unclear. Kingdon (2003, p. 117) lists "analysts for interest groups" and Rüb (2009, p. 355) interest groups representatives as part of policy communities, while Zahariadis (2007, p. 72) does not include them at all. Kingdon's explanatory examples also point to different associations as being involved in advocating certain solutions (e.g., the American Medical Association's involvement in the national health insurance reform in the 1970s; 2003, p. 123). The members of policy communities can come from both inside and outside governmental structures. But they have to be aware of each other, their ideas, and proposals, but often have personal interactions (Kingdon 2003, p. 117). Thus, by interacting with other members of the community and making their positions salient, groups can increase their chance of becoming members themselves.

Kingdon (2003, p. 118) stated that policy communities differ in different policy areas, ranging from closed, tight-knit communities to larger, more diverse, fragmented communities. The tight-knit communities resemble the advocacy coalitions within policy subsystems as defined in the advocacy coalition framework (ACF; Sabatier 1998). They are long-lasting, stable, and integrated coalitions which produce new solutions only when faced with a shock originating outside the subsystem (Sabatier 1998, p. 105). This results either in one dominant coalition being replaced by another (Radaelli 1999, p. 666) or in a context which encourages competing coalitions to find a compromise superior to the status quo by devising a positive-sum solution rather than engaging in a zero-sum fight (Sabatier 1998). Closed, tight-knit communities appear usually in corporatist systems of interest mediation where interest groups gain access to policymaking by ensuring the implementation of policies and thereby adding to overall steering capacity of the state (Jordan 1990; Schmitter 1989). 
The research on interest groups' participation in policymaking tells us that groups' involvement is becoming more temporal, ad hoc, and fluid (Christiansen et al. 2010, p. 32). In the context of eroding corporatism, governments have opportunities to make selective use of some groups, based on their resources. This strategy of a controlled inclusion primarily strengthens the government itself. Since governmental politics is dominating, the patterns of interest mediation are subject to fluctuation. Furthermore, a change of government is likely to result in a changed pattern of interest mediation (Rehder 2009, p. 270).

This results in various arrangements (e.g., commissions, committees, boards) producing different ideas. These subsequently enter the policy stream abruptly and compete with each other to garner the attention of politicians. Consequently, the communities become larger and more fragmented and are characterized by a more competitive mode of interaction. As such, interest groups are not systematically involved in policymaking, and their involvement is more sporadic.

The temporal, larger and less integrated communities are especially prominent at the supranational level. The EU's communities consist of complex networks of insider and outsider actors (Marks 1993; Marks et al. 1996), which are not guided by clear institutional structures but, rather, show little or no formalization (Ainsworth 2001), are limited in their duration, and have a single issue profile. Actors have considerable autonomy and are open to changing their beliefs and their preferences as long as doing so helps them meet their ultimate goals. As such, good arguments can matter even more than bargaining power at the EU level (Pollack 2005). Information exchange seems to play an especially crucial role in creating and sustaining these communities.

When considering interest groups' inclusion in the EU policy communities, some authors suggest that community formation is an effect of long-standing partnerships between actors working on similar issues (Mazey and Richardson 2007; Greenwood 1997; Rietig 2014). However, others provide evidence that EU interest groups form or participate in short-term, ad hoc coalitions which are more suitable to the supranational, dynamic EU environment and its issue arenas (Pijnenburg 1998; Warleigh 2000; Rozbicka 2013). Interest groups' 
influence and participation in the EU communities are related to the groups' ability to efficiently transform and transmit information (Chalmers 2011; Bouwen and McCown 2007; Coen 1997). As EUlevel policymaking is separate from the national implementation efforts, interest group involvement in implementation efforts plays only a minor role for groups' incorporation into the community (Knill and Liefferink 2007; Falkner et al. 2005).

In sum, when it comes to interest groups' participation in the policy stream, the focus should be more on temporal arrangements, where interest group involvement is more ad hoc, than on homogenous and closed communities. Established interest groups can no longer assume they will be included, which may also give rise to new opportunities for previously excluded groups and their ideas.

\section{Politics stream}

The politics stream has been subject to several re-conceptions, which has also affected the role of interest groups within it. In Kingdon's framework, which was developed for the pluralist, US-presidential system, interest groups pressing their demands on government activities join the national mood and turnover in government as important variables for explaining agenda prominence. Adapting the original framework to countries with relatively centralized political systems and strong political parties, such as in European parliamentary systems, Zahariadis put organized interests with the national mood and legislative or administrative turnover into one variable - the "ideology of governing parties" (Zahariadis 1999, p. 79). However, he underlined that politicians often view the support or opposition of interest groups as an indication of consensus or dissent in the broader political arena. In the case of conflicting views, politicians' perception of the balance of support and opposition affects the issue's prominence or obscurity on the agenda (Zahariadis 1999, p. 75, 2007, p. 73).

The interest intermediation literature specifies the conditions for groups' influence. Korpi (1983) showed that in market-based economies, unions and employers inhibit fundamental power resources by representing the workforce and controlling production means, respectively. However, a large membership base and control over 
crucial resources do not guarantee interest groups' influence on government parties (Kingdon 2003, p. 51). In particular, in times of loosening electoral ties, governments tend to balance organized interests with the national mood, which shifts from time to time (Trampusch 2003). In addition, the interplay between organizations and the government is strongly affected by campaigns and the electoral cycle (Rehder 2009, p. 270).

While Zahariadis' focus on of party politics makes sense in parliamentary democracies, it is not suitable for the analysis of supranational policymaking, where party politics plays only a minor role. In the EU, interest groups are not as dependent on party politics to influence the policy process as at the national level. The ability to lobby both national and EU-level politicians means the number of access points is larger (Greenwood 2007; Kresi et al. 2006; Cram 2001). In particular, at the EU level, the access of groups to different institutional actors, including the CEC, the EP, the Council of European Union, and their subunits, is less formalized. Furthermore, lobbying is the accepted and expected form of interest intermediation at the EU level (Daviter 2011 ; Peters 2001). Authors agree that success at this level depends on skillful use of all available resources (Bouwen 2004; Chalmers 2011; Peters 2001). Because of the fluidity of the institutions and the absence of a central EU authority, groups are empowered to use their skills more effectively (Zahariadis 2008, p. 527). In addition, building a network of supporters who have skills, interest, and capacities helps policy participants to achieve their goals (Weible et al. 2012, p. 13). AQ1

Based on these insights from the interest group literature, we claim that the explanatory potential of including interest groups into the MSF is contextually conditioned by the decision-making level under consideration. When studying the politics stream at the national level, scholars should concentrate on how interest groups employ their resources and how their interests are accepted by the national mood and the governing parties. In contrast, at the supranational level, where interests' intermediation is not dependent on party politics, interest groups' skillful use of available resources will be a more useful explanatory variable. 


\section{Illustrative case studies}

To illustrate our arguments, we offer examples from two policy areas where interest groups are important actors in policymaking. First, we examine an instance of policymaking in German labor market policies, where the peak associations of labor and industry play a strong role due to their importance in implementing policies. Employers and unions are of special significance for the dynamic of the three streams.

While labor market policy is still mainly decided at the domestic level, other policy areas in Europe are communitarized, which means that the main decision takes place at the European level. In those policy areas, lobbyism is therefore focused on the European level. As an illustrative case study at the supranational level, we bring up the harmonization of chemicals control in Europe, which is, to date, considered the most extensive exercise in interest group participation in European policymaking (Wonka 2008).

Probing at different levels and focusing on different topics add nuance to the argument and reduce external validity threats by enhancing generalization of results (Lucas 2003; Shadish et al. 2002). Moreover, the application across different levels helps us to compare the effect of different institutional configurations on interest groups' inclusion in the framework. This approach in particular addresses the criticism that the MSF does not adequately display how institutional venues structure agenda setting and policymaking (Schlager 2007; Tiernan and Burke 2002).

\section{National level: German labor market policies}

In the early 1990s, the lack of fundamental reform in social policy initiated a debate over German business competitiveness on the world market, with employers arguing that the highly regulated labor market and steep social insurance taxes dampened worker productivity (Cox 2001 , p. 491). However, the inclusion of interest groups' representatives in labor market policy formation prevented an agenda which included discussion of far-reaching reforms. The fact that such agenda setting did not take place until 2002 can be explained by including organized interest as a variable in all three streams. 
Problem stream: the role of social partners in problem definition

The strong role of the social partners in problem definition is starkly illustrated in the case of the 1998 "Bündnis für Arbeit" (Alliance for Work), a tripartite social-pact for enhancing employment and competitiveness. The red-green coalition led by Chancellor Schröder consulted the Confederation of German Trade Unions and the Confederation (DGB) of German Employers' Associations (BDA) to initiate a policy's reform in 1998. The pact created a "Workgroup on Benchmarking" composed of economists and social scientists to both define problems and identify proposals to enhance the employment rate.

As a first step, the workgroup compared the German conditions with conditions in other countries, laying the foundation for a reform by reaching a mutual interpretation of problems (Fels et al. 1999). Among other things, the group defined the high level of non-wage costs and the excluding effects of German wage policy for low-skilled jobs as problematic. However, this problem definition was rejected by the unions, which feared that this would encourage the widening of a lowpay sector via non-tariff zones and a potential erosion of standard wages. The workgroup's interpretation of indicators did not fit the perceptions and arguments of unions and employers, both of which demanded alternative formulations (Heinze 2006, p. 94). Consequently, problem definition became difficult when unions and the employers' associations joined in the discussion, seeking to include the workgroup's analyses into their strategies. This example shows that groups embedded in national policymaking are in a strong position to interpret indicators and can move items off the agenda by framing conditions as not problematic.

Policy stream: erosion of corporatist community and emerging of new policies

The "Bündnis für Arbeit" illustrates how the inclusion of interest groups in policy communities affects the evolution of policies. The workgroup's proposed concepts [reducing non-wage costs for lowskilled jobs and widening the low-pay sector by implementing nontariff zones in combination with a negative tax, tightening eligibility criteria and lowering benefits for long-term unemployed (Fels et al. 1999)] failed to rise to the top of the corporatist policy community due 
to resistance by trade unions, which were convinced that promoting a low-pay sector would erode standard wages (Patzwaldt 2007: 218 -220). Ultimately, the social partners influenced the composition of the working group, including scholars who were closely connected to unions and employers. However, the group's importance was marginalized in the following debates. In general, the proportional interest representation in the pact's steering committee resulted in a permanent stalemate, as the social partners refused to make concessions (Schmid 2003: 73). Since the mode of interaction was less argumentative than focused on conciliation through bargaining, the social partners could only reach settlements with the government when the negotiations had the character of a nonzero-sum game. Thus, corporatism enabled a non-parliamentary redistribution of costs and benefits financed by the government (Czada 2003: 41, 53). However, the short-term, positive-sum game of such a classical tripartite coordination, which allowed a diffuse externalization of the costs of mutual compensation, was no longer a viable option in the context of the financial crisis of the welfare state and the European Common Market integration (Jochem 2009). As a result, the corporatist bargaining no longer led to agreements over controversial issues.

In January 2002, a political scandal, which uncovered manipulated statistics in the German Employment Agency, opened a window of opportunity to set the agenda for a fundamental reform by circumventing the traditional corporatist structures. The scandal highlighted the ineffectiveness of labor market policies and delegitimized not only the system itself, but also the social partners who were involved in implementing policies and administering the employment agency. Therefore, the scandal offered an opportunity to replace the corporatist policy community. Along these lines, the government appointed a commission named after its chairman, Peter Hartz, a well-known entrepreneur of new employment programs. The Hartz Committee was tasked with preparing a reform of labor market policies.

Although some members of the committee came from trade unions and employers' associations, they were not officially included as representatives of these social partners. Instead, the government and 
Peter Hartz chose members who took a sanguine view of free marketforces, including company executives and business consultants. The composition of the committee enabled agreement on recommendations to fundamentally reform the German labor market system (Hartz et al. 2002), which especially conflicted with unions' interests (Spohr 2015: 180). Specifically, their radicalism lay in combining new eligibility rules with a retrenchment and unification of benefits for the long-term unemployed. Thus, the replacement of established interest groups by new actors in the context of eroding corporatism contributed to the emerging of new policies.

Politics stream: interest groups, political parties, and the national $\operatorname{mood}$

Our assumption is that the dynamic of the politics stream can be best understood by focussing on how governing parties judge the acceptance of groups' interests by the national mood. This can be illustrated by the relationship between the German unions and the social democratic party. Immediately after the social democratic government took over in 1998, it took back changes of the previous conservative government in labor market policies and public unemployment insurance. The socalled correction law was a rewarding of the unions for their support in the electoral campaign (Streeck 2003, p. 7).

The social democrats revaluation of the importance of the different organized interests explains the transformation of the Hartz Committee's recommendations into law. While industrial leaders and most parties supported its recommendations, there were strong protests by the trade unions against cuts in unemployment benefits and the new definition of eligibility. However, the national mood turned against the unions and strategies which worked to their disadvantage gained importance even in the social democratic party (Trampusch and 2003, p. 17). This shift in national mood thus served as an incentive for the government to pursue legislation of the Hartz Committee recommendations, resulting in four controversial laws which came into effect in the years 2003 and 2004.

\section{Supranational level: European chemicals regulation}


On the cusp of the twentieth century, the implementation deficit of chemicals regulation across the European Union gave rise to a discussion promoting the revision of the existing system of chemicals control. The core of the debate was how to create regulations which would be broad and effective, aiming to improve human health and the environment through better, earlier identification of the dangerous properties of chemical substances. A number of scholars who subsequently analyzed the process of chemicals regulation in Europe concluded that its development process consisted of a number of turning points that cannot be simply explained by analyzing policymakers' actions and the existence of focusing events (examples: Kjær 2007; Margossian 2007; Wonka 2008). Adding interest groups to the classical MSF approach solves a puzzle of those turning points.

\section{Problem stream: framing based on addressee's needs}

The main conflict over problem definition in the chemicals regulation debate arose between public interest groups and business representatives (Wonka 2008; Kjær 2007). Public interest groups, represented by umbrella environmental organizations (like European Environmental Bureau-EEB, Greenpeace, and Friends of Earth Europe-FoEE), focused on the registration process for dangerous chemicals. Their analysis clearly indicated that the process was ineffective and opaque (CEC 2001). In contrast, business associations (e.g., Verband der Chemischen Industrie-VCI) focused on the negative effects arising from the full transparency provisions of the registration process, which raise costs for companies and thus lead to job losses across Europe (Pesendorfer 2006).

The arguments used by business representatives resonated in particular with the CEC, responsible for the initial draft of the new regulation. Business arguments were framed in such a way as to match feedback sought by the Commission: good understanding of the market (i.e., costs of deployment of the new registration system) and public demands (i.e., job losses). Consequently, the prevailing problem definition presented in the Commission's proposal of the new regulation highly resembled the one delivered by the business associations. The problem of revising the transparency requirements was considered, but the 
Commission initially did not increase these obligations (CEC 2003). This example shows that groups can influence the problem definition of particular policymakers by employing appropriate framing.

Policy stream: low-integrated, supranational policy community The EU chemicals regulation provides an example of a low-integrated community. European institutions consulted a number of different interest groups on various occasions, including holding seven technical working groups between 2001 and 2002, inter-stakeholders' workshops in 2001, 2003, and 2004, as well as EP public hearings in 2005 (CEC 2007). In particular, the working groups and inter-stakeholders' workshops were temporary, with participants fluctuating depending on institutions' needs for particular types of expertise. The result was a fluid policy community whose members were replaced ad hoc.

The ad hoc character of the community resulted in an ongoing redefinition of policy ideas. Initially, the European institutions cooperated mostly with the environmental "giants," like EEB and World Wild Fund (WWF), but also more regional organizations, like the Danish Society for Conservation of Nature. This cooperation resulted in a policy proposal aimed at establishing an ambitious, unified chemicals agenda at the international level, which gained the support of Swedish, Dutch, and Austrian members of the Council (EC 2004). When it became clear that the revision of the chemicals regulation in Europe was unavoidable, more stakeholders were invited to the negotiation table and they brought their own policy ideas. The European chemicals industry and its associations (e.g., CEFIC, BASF) demanded the simplification of existing regulations in order to make them easier to observe and thus a much less ambitious policy solution (Pesendorfer 2006; Schorling 2004). An intensive information exchange took place between business and the conservative members of the EP and the Enterprise Directorate General in the Commission. This cooperation was further supported by German and French trade unions and the British and French national experts located in the Council's structures.

Inclusion of interest groups in the policy community affected the advancement of chemicals policy. From an ambitious project initially championed by environmental organizations, it was transformed into a 
watered down solution with only minor changes to the earlier system of chemicals regulation. For instance, one of the stated goals of the regulation, protection of the environment, was removed from the text of the final policy documents entirely (CEC 2007).

Politics stream: skillful use of resources and window of opportunity

Above, we have argued that when studying the politics stream at the supranational level, scholars should take interest groups' skillful deployment of their resources into account as an explanatory variable. One instance of environmental NGOs taking an anti-industry stance on the chemicals regulation illustrates this well. FoEE (one of the largest European environmental NGOs) started an initiative on October 17, 2006, under the title "EU Commissioners in bed with business," criticizing the close relations between the CEC and corporate lobbying in the chemicals regulation process as inappropriate (FoEE 17/10/2006). Using their network of grassroots national organizations (the group resource in form of its membership base), FoEE was able to reprint the images from the initiative across national arenas.

Consequently, national representatives in the Council requested the Commission to alter its behavior. Thus, the skillful use of the groups' membership base allowed it to influence the public mood at the national level across countries and to impact the European, supranational level.

While NGOs managed to impact on the behavior of the main stakeholders, they still failed in exercising larger influence on the final result of the policymaking process. The actions undertaken by business representatives were much more successful. A number of business associations involved in the chemicals regulation (e.g., CEFIC, BASF, VCI) recognized the review of the Lisbon Strategy (2003) - a document which was developed in parallel to the chemicals regulation and looked to make the EU the most competitive economic space in the world-as a political window of opportunity. Accordingly, they framed further regulation as a stumbling block toward achieving the Lisbon Strategy's goals (Schorling 2004). This proved to be an additional catalyst for the adoption of a less restrictive regulation. Ultimately, the document resulting from this process, the "REACH" Regulation (2006), introduced only few minor changes relative to the policy documents 
from the 1990s (i.e., minor adjustments to the registration procedure). A skillful deployment of framing (e.g., linking groups' arguments with the window of opportunity) resulted in an outcome which barely affected the chemicals industry in Europe.

\section{Summed up}

Our case studies illustrated the theoretical arguments derived from the MSF's definitions and the interest intermediation literature from the previous section. We showed that interest groups can take active roles in the three streams. In the problem stream, the negative role of the German trade unions in the "Bündnis für Arbeit" provided an example showing that groups embedded in national policymaking are in a position to move items off the agenda by framing conditions as unproblematic. In contrast, the EU chemicals regulation illustrated how interest groups were successful in framing the problem to match their favored solution, which they placed simultaneously in the policy stream. Delivered feedback, based on the needs of the CEC, proved to be an important access good for these interest groups in the problem stream.

Germany's labor market policy community was perennially homogenous and closed to the inclusion of new actors and ideas. Fundamentally new policies could only emerge due to the replacement of established interest groups by new actors in the context of eroding corporatism. In the low-integrated, supranational community, participation of groups was fluctuating and based on information and expertise that they could deliver. The intensified information exchange between business representatives and the key EU stakeholders in the later stages of the policy's development resulted in a much less ambitious policy alternative than originally suggested.

In the politics stream at the national level, government balanced interests against the national mood. A shift in national mood against the unions served as an incentive for the government to pursue legislation. At the European level, NGOs' use of their membership base influenced the behavior of the Commission and the Council. And yet, by combining the framing of their argument with the use of the political window of opportunity, business groups altered the policy development. 
Both instances are examples of skillful actions of interest groups which resulted in measureable changes.

\section{Where do we go from here?}

In this article, we have explored how to include interest groups in the MSF analysis and the factors which could improve the explanatory power of such a combination. As we showed in our illustrative cases, the inclusion of interest groups in the MSF analysis can on the one hand explain the redefinition of both problems and solutions and show how they are coupled into a policy. Thus, interest groups are likely to take over the role of policy entrepreneurs, especially since agenda setting and policy changes require someone who takes advantage at the right time to match policies to problems. And the best way of developing a sense of timing is to participate for extended periods of time (Weible et al. 2012: 15); something interest groups certainly are capable to do due to their good contacts, financial resources, and manpower. On the other hand, however - and in contrast to problem brokers and policy entrepreneurs - interests groups do not only pursue their own goals, but also aim to avoid the agenda setting of certain problems and policies and thereby hinder the coupling process. The insights from the interest intermediation literature informed us of the conditions which enhance interest groups' role in the three streams and could be tested more extensively in future research.

First, we suggest that the power of interest groups over problem definition is a sum of their framing skills and the feedback that they provide. On the national level, the impact of groups on the problem stream can be explored through the prism of their embeddedness in the domestic institutional system. On the European level, their impact stems from the information about economic and public demands required by policymakers. An important role in the policy stream is granted to those interest groups at the national level that ensure a proper implementation of the policies. At the European level, delivering expertise and information exchange are crucial resources to gain importance in developing policies. While exploring policy communities, we established that when interest groups are involved, the researcher has to deal with more temporal arrangements rather than long-lasting policy 
communities. Doing so will result in a better explanation of the increased contingency in the policy stream. In the politics stream, we concluded that interest groups' success at the national level is dependent on party politics and a match of groups' interests with the national mood. At the European level, party politics and national mood play only a minor role. The analysis of groups' resources and their deployment will be more informative.

Including interest groups in the MSF holds considerable potential. Since the empirical evidence offered here remains only illustrative, however, further rigorous tests are needed to probe the validity of our arguments. In particular, comparative studies involving different policy areas with different issue characteristics are necessary. After all, the arguments presented here on labor market and chemicals regulation may be invalid in relation to defense policies due to security issues and considerations of general public safety. As such, scholars could usefully examine whether different conditions than those presented in this article guide interest groups' inclusion in the framework.

\section{Acknowledgments}

We wish to thank Nikolaos Zahariadis and the participants of the "Ambiguity and Public Policy" Workshop, at the Department of Government, College of Arts \& Sciences, University of Alabama at Birmingham, AL, USA, November 14-15, 2014. We are also thankful to Tom Birkland, Laura Carsten-Mahrenbach, Hanno Hahn, and the anonymous reviewers for their helpful comments on earlier versions of this article.

\section{References}

Ainsworth, S. (2001). Lobbying together: Interest group coalitions in legislative politics. American Political Science Review, 95(2), 475 -575 .

Baumgartner, F. R., \& Jones, B. D. (1991). Agenda dynamics and policy subsystems. Journal of Politics, 53(4), 1044-1074. 
Bendel, P. (2006). Migrations- und Integrationspolitik der Europäischen Union: Widersprüchliche Trends und ihre Hintergründe. In S. Baringhorst, U. Hunger, \& K. Schönwälder (Eds.), Politische Steuerung von Integrationsprozessen. Intentionen und Wirkungen (pp. 95-120). Wiesbaden: VS.

Beyers, J. (2002). Gaining and seeking access: The European adaptation of domestic interest associations. European Journal of Public Research, 41(5), 585-612.

Binderkrantz, A. (2005). Interest groups strategies: Navigating between privileged access and strategies of pressure. Political Studies, 53(4), 694-715.

Boscarino, J. E. (2009). Surfing for problems: Advocacy groups strategy in U.S. Forestry Policy. Policy Studies Journal, 37(3), 415 -434 .

Bouwen, P. (2002). Corporate lobbying in the European Union: The logic of access. Journal of European Public Policy, 9(3), 365-390.

Bouwen, P. (2004). Exchanging access goods for access: A comparative study of Business Lobbying in the EU Institutions. European Journal of Political Research, 43(3), 337-369.

Bouwen, P., \& McCown, M. (2007). Lobbying versus litigation: Political and legal strategies of interest representation in the European Union. Journal of European Public Policy, 14(3), 422 -443 .

Bundgaard, U., \& Vrangbæk, K. (2007). Reform by coincidence? Explaining the policy process of structural reform in Denmark. Scandinavian Political Studies, 30(4), 491-520.

CEC. (2001). White Paper: Strategy for a future Chemicals Policy. COM (2001) 88 final. Brussels. 
CEC. (2003). Proposal for a regulation of the European parliament and of the council concerning the registration, evaluation, authorisation and restriction of chemicals (Reach), establishing a European Chemicals Agency and amending Directive 1999/45/EC and Regulation (EC). Brussels.

CEC. (2007). REAH, Directorate General Environment http://ec.europa.eu/environment/chemicals/reach/reach_en.htm, last accessed 20/05/2011.

Chalmers, A. W. (2011). Interests, influence and information: Comparing the influence of interest groups in the European Union. Journal of European Integration, 33(4), 471-486.

Christiansen, P. M., Nørgaard, A., Rommetvedt, H., Svensson, T., Thesen, G., Öberg, P. (2010). Varieties of democracy: Interest groups and corporatist committees in Scandinavian policy making, In: Voluntas, 21, pp 22-40.

Coen, D. (1997). The evolution of the large firm as a political actor in the European Union. Journal of European Public Policy, 4(1), 91 -108 .

Cox, R. H. (2001). The social construction of an imperative. Why welfare reform happened in denmark and the Netherlands but not in Germany. World Politics, 53(3), 463-498.

Cram, L. (2001). Integration theory and the study of the European policy process. In J. Richardson (Ed.), European Union: Power and policy-making (pp. 51-73). London: Routledge.

Czada, R. (2003). Konzertierung in verhandlungsdemokratischen Politikstrukturen. In S. Jochem \& N. Siegel (Eds.), Konzertierung, Verhandlungsdemokratie und Reformpolitik im Wohlfahrtsstaat. Das Modell Deutschland im Vergleich (pp. 35-69). Leske: Opladen.

Daviter, F. (2011). Policy framing in the European Union. New York: Palgrave Macmillan. 
EC. (2004). Council of the European Union Ad hoc Working Party on chemicals. Outcome of Proceedings, 24 May 2004 9445/04.

Falkner, G., Treib, O., Hartlapp, M., \& Leiber, S. (2005). Complying with Europe. EU Harmonization and Soft Law in the Member States. New York: Cambridge University Press.

Fels, G., Heinze, R. G., Pfarr, H., Streeck, W. (1999). Bericht der Wissenschaftlergruppe der Arbeitsgruppe Benchmarking über Möglichkeiten zur Verbesserung der Beschäftigungschancen gering qualifizierter Arbeitnehmer, Bundesregierung.

FoEE. (17/10/2006). EU Commission in Bed with Business. Press Release.

http://www.foeeurope.org/press/2006/joint_17_Oct_UNICE_bed_action.h Accessed 26 March 2014.

Greenwood, J. (1997). Representing interest in the European Union. London: Macmillan.

Greenwood, J. (2007). Interest representation in the European Union (2nd ed.). New York: Palgrave MacMillan.

Hall, R. L., \& Deardorff, A. (2006). Lobbying as legislative subsidy. American Political Science Review, 100(1), 69-84.

Hartz, P. et al. (2002). Moderne Dienstleistungen am Arbeitsmarkt. Vorschläge der Kommission zum Abbau der Arbeitslosigkeit und zur Umstrukturierung der Bundesanstalt für Arbeit.

Heinze, R. G. (2006). Wandel wider Willen. Deutschland auf der Suche nach neuer Prosperität. Wiesbaden: VS.

Jochem, S. (2009). Skandinavische Beschäftigungspolitik-Stärken und Schwächen im internationalen Vergleich. WSI Mitteilungen, 1 (2009), 3-9. 
Jordan, G. (1990). The pluralism of pluralism: An anti-theory? Political Studies, 38(2), 286-301.

Kingdon, J. W. (2003). Agendas, alternatives, and public policies (2nd ed.). Boston/Toronto: Longman.

Kjær, A. M. (2007). Rationality within REACH? On Functional Differentiation as the Structural Foundation of Legitimacy in European Chemical Regulation, EUI Working Papers.

Knaggård, Å. (2015). The multiple streams framework and the problem broker. European Journal of Political Research, 54(3), 450 -465 .

Knill, C., \& Liefferink, D. (2007). Environmental politics in the European Union: Policy-making, implementation and patterns of multi-level governance. Manchester: Manchester University Press.

Kohler-Koch, B. (1994). Changing patterns of interest intermediation in the European Union. Government and Opposition, 29(2), 166-180.

Korpi, W. (1983). The democratic class struggle. Boston: Routledge \& Kegan Paul.

Kresi, H., Adam, S., \& Jochum, M. (2006). Comparative analysis of policy networks in Western Europe. Journal of European Public Policy, 13(3), 341-361.

Lowery, D., Poppelaars, C., \& Berkhout, J. (2008). The European Union interest system in comparative perspective: A bridge too far? West European Politics, 31(6), 1231-1252.

Lucas, J. W. (2003). Theory-testing, generalization, and the problem of external validity. Sociological Theory, 21(3), 236-253.

Margossian, N. (2007). Le Reglement REACH. La reglementation europeene sur les produits chimiques. Paris: Dunod. 
Marks, G. (1993). Structural policy and multi-level governance in the EC. In A. Cafruny \& G. Rosenthal (Eds.), The State of the European Community (pp. 391-409). London: Longman.

Marks, G., Hooghe, L., \& Blank, K. (1996). European integration from the 1980s: State-centric v. multi-level governance. Journal of Common Market Studies, 34(3), 341-378.

Mazey, S., \& Richardson, J. (2007). Environmental Groups and the EC: Challenges and opportunities. In A. Jordan (Ed.), Environmental Policy in the European Union. Actors, institutions \& processes (pp. 106-124). London: Earthscan.

Nagel, A. (2009). Politische Entrepreneure als Reformmotor im Gesundheitswesen: Eine Fallstudie zur Einführung eines neuen Steuerungsinstruments im Politikfeld Psychotherapie. Wiesbaden: VS.

Nedlund, A.-C., \& Garpenby, P. (2014). Puzzling about problems: The ambiguous search for an evidence-based strategy for handing influx of health technology. Policy Sciences, 47(4), 367-386.

Öberg, P., et al. (2011). Disrupted exchange and declining corporatism: Government authority and interest groups capability in Scandinavia. Government and Opposition, 46(3), 365-391.

Patzwaldt, K. (2007). Was leistete Politikberatung in den rot-grünen Arbeitsmarktreformen? In K. D. Wolf (Ed.), Staat und Gesellschaft fähig zur Reform? (pp. 211-228). Baden-Baden: Nomos.

Pesendorfer, D. (2006). EU environmental policy under pressure:

Chemicals Policy Change Between Antagonistic Goals?

Environmental Politics, 15(1), 95-114.

Peters, G. (2001). Agenda setting the European Union. In J. Richardson (Ed.), European Union Power and Policymaking (pp. 77 -94). London: Routledge. 
Pijnenburg, B. (1998). EU lobbying by ad hoc coalitions: An exploratory case study. Journal of European Public Policy, 5(2), 303 -321 .

Pollack, M. A. (2005). Theorizing EU policy-making. In W. Wallace \& M. A. Pollack (Eds.), Policy-Making in the European Union (pp. 13-48). Oxford: Oxford University Press.

Quittkat, Ch., \& Kotzian, P. (2011). Lobbying via consultation-Territorial and functional interests in the commission's consultation regime. Journal of European Integration, 33(4), 401-418.

Radaelli, C. M. (1999). Harmful tax competition in the EU: Policy narratives and advocacy coalitions. Journal of Common Market Studies, 37(4), 661-682.

Rehder, B. (2009). Interessenvermittlung in Politikfeldern-ein vergleichendes Fazit 267. In B. Rehder, T. Winter, \& U. Willems (Eds.), Interessenvermittlung in Politikfeldern Vergleichende Befunde der Policy- und Verbändeforschung (pp. 267-273). Wiesbaden: VS.

Rhodes, R. A. W., \& Marsh, D. (1992). New directions in the study of policy networks. European Journal of Political Research, 21(1 $-2), 181-205$.

Rietig, K. (2014). Neutral experts? How input of scientific expertise matters in international environmental negotiations. Policy Sciences, $47(2), 141-160$.

Rozbicka, P. (2013). Advocacy coalitions: Influencing the policy process in the EU. Journal of European Public Policy, 20(6), 838 -853 .

Rüb, F. W. (2009). Multiple-Streams-Ansatz: Grundlagen, Probleme und Kritik. In K. Schubert \& N. C. Bandelow (Eds.), Lehrbuch der Politikfeldanalyse 2.0 (pp. 348-376). München: Oldenbourg. 
Sabatier, P. A. (1998). The advocacy coalition framework: Revisions and relevance for Europe. Journal of European Public Policy, 5(1), 98-130.

Schattschneider, E. E. (1975). The Semisovereign people. A realist's view of democracy in America. New York: Thomson Learning.

Schlager, E. (2007). A comparison of frameworks, theories, and models of policy processes. In P. A. Sabatier (Ed.), Theories of the policy process (pp. 293-319). Boulder, CO: Westview Press.

Schmid, G. (2003). Gestaltung des Wandels durch wissenschaftliche Beratung. Das ,Bündnis für Arbeit' und die ,Hartz-Kommission. In S. Ramge \& G. Schmid (Eds.), Management of Change in der Politik? Reformstrategien am Beispiel der Arbeitsmarkt- und Beschäftigungspolitik. Waxmann: Münster.

Schmitter, P. C. (1989). Corporatism is dead! Long live corporatism! Government and Opposition, 24(1), 54-73.

Schorling, I. (2004). REACH. The only planet guide to the secrets of chemicals policy in the EU. What happened and why?, Brussels, 2004.

Shadish, W. R., Cook, T. D., \& Campbell, D. T. (2002). Experimental and quasi-experimental designs for generalized causal inference (2nd ed.). Boston: Houghton Mifflin.

Spohr, F. (2015). Pfadwechsel in der Arbeitsmarktpolitik. Eine Analyse aktivierender Reformen in Großbritannien Deutschland und Schweden anhand des Multiple Streams Ansatzes. Baden-Baden: Nomos.

Stone, D. A. (2002). Policy paradox: The art of political decision making. New York: Norton \& Co.

Streeck, W. (2003). No longer the century of corporatism. Das Ende des "Bündnisses für Arbeit", MPIfG Working Paper 03/4. 
Tiernan, A., \& Burke, T. (2002). A load of old garbage: Applying Garbage-can theory to contemporary housing policy. Australian Journal of Public Administration, 61(3), 86-97.

Trampusch, Ch. (2003). Von Verbänden zu Parteien. Der Elitenwechsel in der Sozialpolitik, MPIfG Discussion Paper 04/3, Köln: MPIfG.

Truman, D. B. (1951). The Governmental process. Political Interests and Public Opinion. New York: Alfred A. Knopf.

Warleigh, A. (2000). The hustle: Citizenship practice, NGOs and policy coalitions in the European Union - the cases of auto oil, drinking water and unit pricing. Journal of European Public Policy, $7(2), 229-243$.

Weible, C. M., Heikkila, T., deLeon, P., \& Sabatier, P. A. (2012). Understanding and influencing the policy process. Policy Sciences, 45(1), 1-21.

Wonka, A. (2008). Europeanized convergence? British and German business associations' European lobbying strategies in the formulation of REACH. In R. Grote, A. Lang, \& V. Schneider (Eds.), Organised business interests in changing environments (pp. 179-199). Houndmills: Palgrave Macmillan.

Zahariadis, N. (1999). Ambiguity, time, and multiple streams. In P. Sabatier (Ed.), Theories of the policy process (pp. 73-93). Oxford: Oxford University Press.

Zahariadis, N. (2007). The multiple streams framework: Structure, limitations, prospects. In P. A. Sabatier (Ed.), Theories of the policyprocess (2nd ed.). Boulder: Westview Press.

Zahariadis, N. (2008). Ambiguity and choice in European public policy. Journal of European Public Policy, 15(4), 514-530. 
Zahariadis, N. (2014). Ambiguity and multiple streams. In P. Sabatier \& Ch M Weible (Eds.), Theories of the policy process (pp. 25-58). Boulder, CO: Westview Press. 